\title{
Obtaining characteristics of FMM displacement sensor by applying a flick standard
}

\author{
Wyznaczanie charakterystyk czujników przemieszczeń \\ urządzeń FMM z użyciem wzorca ze ścięciem
}

\begin{abstract}
MARTA WIŚNIEWSKA SABINA ŻEBROWSKA-ŁUCYK*
\end{abstract}

A novel method for obtaining characteristics of displacement sensors applied to form measuring machines is presented. In order to find the characteristic curves of such sensors, flick standards are adopted. In the paper, besides the core idea of this calibration method, there is an influence of some of the most important factors affecting calibration uncertainty presented.

KEYWORDS: FMM, flick standard, sensor nonlinearity, calibration

Przedstawiono nową metodę wyznaczania charakterystyk czujników urządzeń FMM wykorzystującą szeroko rozpowszechnione wzorce ze ścięciem. Wskazano czynniki wpływajace na niepewność wyznaczenia charakterystyki oraz oszacowano znaczenie wybranych czynników.

SŁOWA KLUCZOWE: FMM, wzorzec ze ścięciem, nieliniowość charakterystyki czujnika, wzorcowanie

In the recent years a significant progress in assessing departures of mechanical elements from their nominal form has been observed. Not only have algorithms of data processing been improved, but also numerous sophisticated form measuring machines - FMMs - differing in their construction, measuring range and resolution - came onto the market. Due to this advancements, applicability of the form measuring machines is no longer limited to macrotexture measurements but is opening up the whole new fields such as surface roughness' or dimensions' metrology.

However, vast majority of FMMs' improvements introduced by the leading manufacturers aim not to improve the measurements' accuracy but just increase usability and range of potential applications of metrological equipment of the kind. Fulfilling such ambitions has a severe side effect: it usually results in worsening important metrological parameters, i.e. indication errors of the displacement sensor. However, this is the sensor that is instrumental in ensuring sufficient accuracy of all form deviations' measurements. Therefore, a recognition and correction of indication errors of the sensor is crucial for exact measurements with a use of the FMM. In the paper, a method for doing so is outlined.

At first sight, both detection and compensation of the indication errors seems to be a trivial issue. However, due to specific conditions the sensor works under, the problem turns to be thorny. Not only has the sensor to combine wide measuring ranges (exceeding a millimeter) with high resolutions (up to single nanometers), but also it ought to remain as small and light as possible. Also, when measurements of complicated mechanical elements are being carried out, the sensor orientation (horizontal, verti-

\footnotetext{
* Mgr inż. Marta Wiśniewska (martwisn@mchtr.pw.edu.pl), dr hab. inż Sabina Żebrowska-Łucyk (szl@mchtr.pw.edu.pl) - Instytut Metrologii i Inżynierii Biomedycznej, Wydział Mechatroniki Politechniki Warszawskiej
}

\author{
DOI: https://doi.org/10.17814/mechanik.2017.11.174
}

cal) and angular position or force of stylus arm is usually changed numerous times (fig. 1). To make matters worse, the stylus arms have to be replaceable to make complex measurements possible. In order to meet these huge demands, the inductive sensors (fig. 2), in which an armature connected to an interchangeable stylus arm moves between 2 coils changing their inductance, are applied to the FMMs.

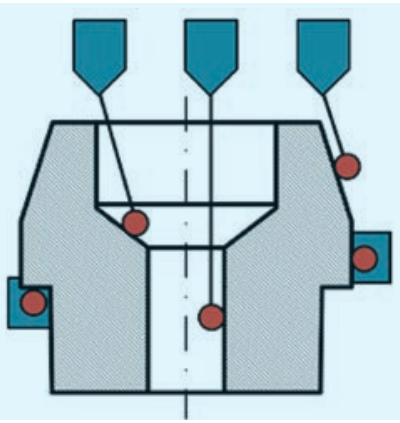

Fig. 1. Measurement of a complicated mechanical element

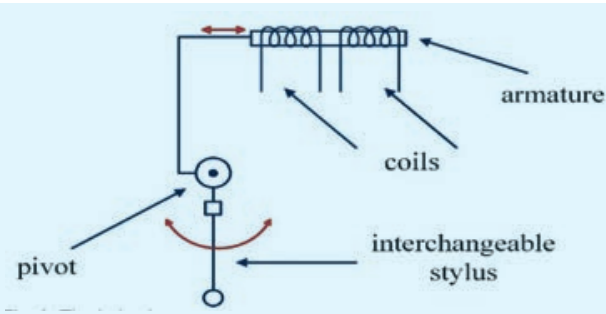

Fig. 2. The inductive sensor

In spite of the fact that correction of the sensor indication errors introduced by its inductive part may be performed by the producer during manufacturing process, the errors caused by angular position of a stylus depend on the current stylus position and, in result, they usually have to be determined and corrected numerous times during the measurement of a single mechanical part. For the sake of estimating the indication errors caused by angular position of a stylus some simple calculations have been made. Their results are presented in fig. 3.

As the chart clearly indicates (fig. 3), the indication errors e may exceed tens of micrometers if stylus angular position $\alpha$ referring to sensor's 0 indication is larger than a few degrees. The $\beta$ angle corresponds with changes of stylus angular position within the sensor measuring range of $\pm 1,03 \mathrm{~mm}$.

Despite the utmost importance of, at first, determining and then also compensating sensors' indication errors, there are hardly any solutions to this problem. Most of them, i.e. $[1,2]$, enable user to estimate only a sensor's amplification coefficient referring to the slope of sensor characteristics, but not a sensor's characteristics nonlinearity. However, the measurement errors caused by 
the nonlinearity of sensor's characteristics may even exceed the form deviations being measured. Therefore, other solutions [3-5] were born out of this necessity for obtaining comprehensive information concerning sensor's characteristics. Nevertheless, they have some severe drawbacks. For example, the method [3] requires using additional measurement stand what makes it difficult to be applied by the FMM's user. Another method [4] demands using a specialized non-typical stylus that is not used during the measurements of mechanical parts, whereas the [5] is not applicable to instruments that do not give an opportunity to perform measurements in the direction which is parallel to the machine's column and, to make matters worse, requires using a costly calibration standard.

The method that is proposed in the paper is free of these limitations.

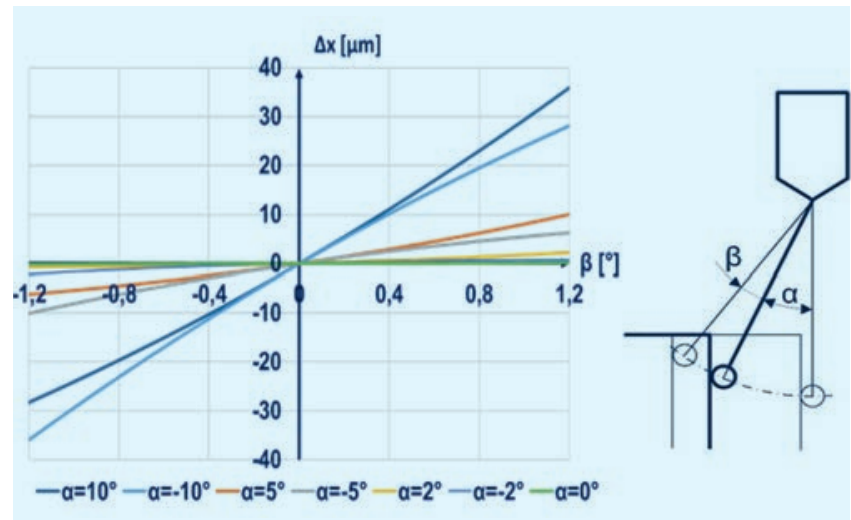

Fig. 3. Stylus angular position during the measurements of mechanical parts (Talymin 5 gauge, stylus length: $100 \mathrm{~mm}$, measuring range: $\pm 1,03 \mathrm{~mm}$ )

\section{Theoretical basis}

The theoretical fundamentals of the proposed method have already been presented in detail during IMEKO World Congress in 2015 [6]. However, in order to keep the disquisition clear, the authors decided to outline the crucial issues once more.

A few assumptions have been made as a basis for the recommended method. Firstly, it was presumed that the sensor's characteristics crosses the origin point $(0,0)$, as the nominal sensor measuring ranges are symmetrical to 0 (i.e. $\pm 500 \mu \mathrm{m}$ ). Also, the authors assumed that the sensor characteristics can be described effectively by the polynomial of $k$-degree (usually of the $3^{\text {rd }}$ or $5^{\text {th }}$ one) [7].

In effect, a function which relates gauge readings $x$ to real stylus displacements $y$ (fig. 4) is:

$$
y=f(x)=\sum_{j=1}^{k} a_{j} x^{j}
$$

where: $a_{j}$ are the polynomial coefficients.

Due to sensor indication errors, an increase of the measuring signal $\Delta x_{i}$ responds to a constant increase of a given stylus displacement $\Delta y_{i}=w$ (fig. 4). If measurements of the stylus $\Delta y_{i}=w$ are performed in at least $k$ points within the sensor measuring range, the matrix $\left(x_{i} ; \Delta x_{i}\right)$ is given and for the known $w$ values, the derivative of $f(x)$ function values, referring to sensor reading $x_{i}$ can be determined as it is shown in (2).

$$
\left.\frac{\mathrm{d} y}{\mathrm{~d} x}\right|_{x=x_{i}} \cong \frac{w}{\Delta x_{i}}=\kappa_{i}
$$

After approximating set of data points $\left(x_{i} ; \mathrm{K}_{i}\right)$ with a polynomial of $k-1$ degree, the coefficients $a_{j}$ can be calculated. A sensor characteristics is determined this way.

Then, by subtracting $y$ from $x$ values the indication errors $e$ are calculated. After subtracting regression line from the obtained function $e(x)$, also the nonlinearity errors $e_{l}(x)$ can be given. If these errors are known, the essential corrections may be made, as well.

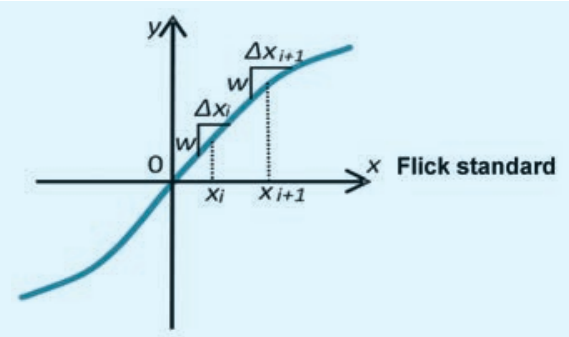

Fig. 4. Sample characteristics of the sensor; $x$ - reading of the calibrated gauge; $y$-correct reading (real stylus displacement)

\section{Flick standard}

The flick standards have already been common in the laboratories of dimensional metrology, but, as aforementioned, they have been used to estimate just a sensor amplification not the full sensor characteristics. Due to their prevalence, these standards have been chosen as the reference ones and their depth reflects the measurand value $w$. Another advantage of using flick standards is their diversity: the nominal depths may vary from a few up to hundredths micrometers. However, the diameters of such standards should not be larger than several millimeters, as with increasing diameter, the manufacturing process becomes unnecessarily difficult and expensive due to the hardship resulting from the fact that the reference, cylindrical part, has to have extremely low form deviations.

\section{Implementation and verification}

In order to verify the method's applicability, numerous measurement of a flick standard $(w=48,0 \mu \mathrm{m})$ have been conducted with a use of Talyrond 200 form measuring machine.

Before initiating each measurement series the operator had ensured that axes of rotation and calibration standard are parallel and centric. Without doing so, the measurement results would be significantly biased and, therefore, the obtained sensor characteristics would be severely distorted.

Then, the flick standard was measured numerous times. During each measurement a slightly different part of measuring gauge's range (set to $1 \mathrm{~mm}$ ) was used. This effect was produced by moving a sensor outward or backward the standard before each measurement of a single circumferential profile.

Next, every circumferential profile measurement result was analysed and $k_{i}$ values were calculated. In order to do so, the least square circle is fitted to the registered profile. However, the data which is used to do so, is the part of a signal that is not distorted at all by a flick. Then, the maximum local deviation from the reference circle, which refers to the measured flick depth, is calculated. Finally, the measured $L R D_{m}$ and the nominal values $w$ are compared:

$$
\kappa_{i}=\frac{w}{L R D_{m}}
$$




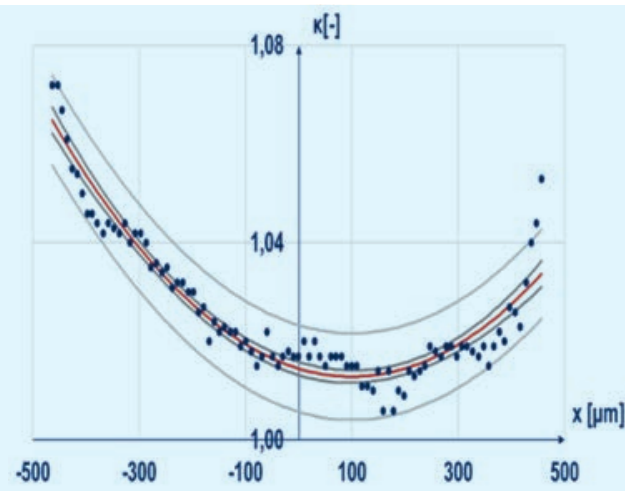

Fig. 5. $\boldsymbol{\kappa}_{i}$ values worked out experimentally

The $\kappa_{\mathrm{i}}$ values obtained in the research are presented in fig. 5. The dotted line refers to a polynomial fitted to them. The polynomial equation is as follows:

$$
g(x)=1,642 \cdot 10^{-7} x^{2}-3,275 \cdot 10^{-5} x+1,014
$$

In result, it is possible to calculate coefficient of the $3^{\text {rd }}$ degree polynomial describing the sensor characteristics:

$$
y(x)=5,475 \cdot 10^{-8} x^{3}+1,638 \cdot 10^{-5} x^{2}+1,014 x
$$

Therefore, the sensor indication errors $e$ are:

$$
e(x)=-5,475 \cdot 10^{-8} x^{3}+1,638 \cdot 10^{-5} x^{2}-0,014 x
$$

After excluding regression line from $e(x)$, the linearity errors $e_{l}(x)$ are obtained:

$$
e_{l}(x)=-5,710 \cdot 10^{-8} x^{3}+1,640 \cdot 10^{-5} x^{2}+7,743 \cdot 10^{-3} x
$$

In order to assess reliability of the sensor characteristics given with the proposed method, the results have been compared to the ones obtained with the reference method [3]. The results are presented in. fig 6.

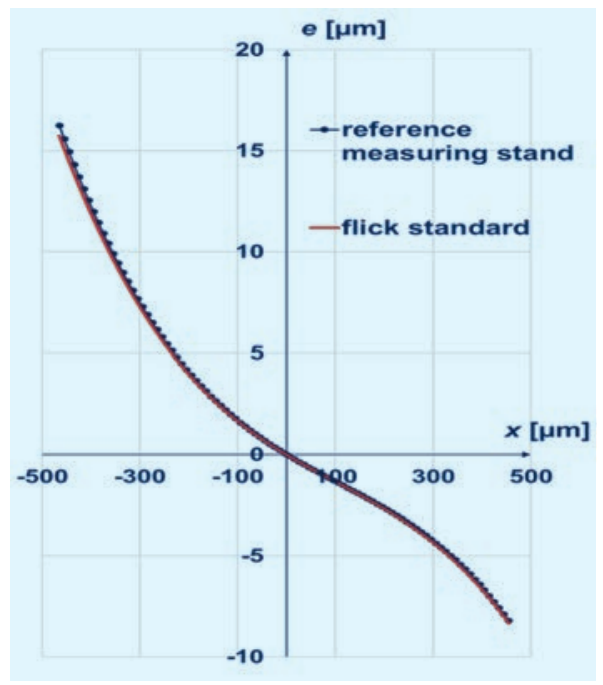

Fig. 6. The experiment's final results

\section{Factors affecting the uncertainty}

In spite of the promising results achieved in the already conducted experiments, both the proposed method of estimating sensor characteristics itself and a choice of calibration standard entails the necessity for identification of the key factors that may impose limits on the applicability of the recommended solution or extensively increase the uncertainty of sensor characteristics estimation.

Firstly, further investigation referring to optimum dimensions of a standard: diameter and depth of a flick, is yet to be made. It is mainly due to the fact that deep flicks may cause significant errors by introducing linearization of the characteristics.

Also, it is worth considering if a flick standard itself is the best calibration artifact, as the results obtained with it are dependent on the numerous factors, number of points of a single circumferential profile especially. The other forms of the standard may turn out to be more effective and give smaller contribution to the overall method uncertainty budget.

Among the other factors that may influence the obtained surface characteristics there are:

- eccentricity and non-parallelism of the rotation and calibration standard axes;

- data processing, i.e. a choice of the reference element or data filtration;

- resolution of the instrument's sensor;

- number and positioning of calibration points within measuring range.

Last of the presented factors is especially important, as a number of calibration points used in the introductory research is not acceptable from practical point of view. In effect, further research limiting this number to a reasonable one (not exceeding 10) without affecting method's accuracy significantly is required.

\section{Conclusion}

The proposed method seems to answer a need for fast and effective way of estimating FMMs' sensors indication and linearity errors and then compensating them in order to increase accuracy of form deviation measurements.

Firstly, the recommended solution may be applied efficiently from not only FMM's manufacturer, but also from its end user's point of view. It is due to the fact that the calibration procedure may be easily automatized and interpretation of the results is quite intuitive.

Moreover, manufacturing flick standards is fast and cost-effective. When popularity of the flick standards in the metrological laboratories is considered as well, the proposed method seems to be easily put on the map of advanced dimensional metrology.

However, further investigation referring to the uncertainty of determining sensor characteristic is required. Not until then, applying the devised method widely will be possible.

This work was supported by the grant of the Dean of Faculty of Mechatronics (Warsaw University of Technology).

\section{REFERENCES}

1. Jusko O., Bosse H., Flack D., Hemming B., Pisani M., Thalmann R. "A comparison of sensitivity standards in form metrology - final results of the EURAMET project 649". Meas. Sci. Technol. 23, 054006 (2012): pp. 1-7.

2. Jusko O., Ludicke F. "Novel multi-wave standards for the calibration of form measuring instruments". Braunschweig: PTB, 1999.

3. Kadłubowski D., Rudziński R., Żebrowska-Łucyk S. „Stanowisko i oprogramowanie do wyznaczania błędów wskazań czujników indukcyjnych", Prace Naukowe PW. 3 (1994): pp. 297-300.

4. Żebrowska-Łucyk S., Czapski M., Rudziński R. "Fast method for non-linearity of FMM displacement sensors characteristics examination" VII Coordinate Measuring Technique Conference. Bielsko-Biała, 2006, pp. 61-69.

5. Żebrowska-Łucyk S. "A method for determining systematic errors of probes measuring displacements". Proc. 6 ${ }^{\text {th }}$ ISMQC IMEKO Symposium Metrology for Quality Control in Production. Vienna, 1998, pp. 735-742.

6. Wiśniewska M., Żebrowska-Łucyk S. „Determination of form measuring machine displacement sensor characteristics with a use of flick standard". Proc.. XXI IMEKO World Congress, 2015. Prague, 2015, pp. $1575-1579$.

7. Zebrowska-Łucyk S., Gościmski J., Rudziński R. et al. „Opracowanie modelu komputerowego stanowiska do pomiaru odchyłek kształtu i położenia powierzchni elementów i zespołów mechanicznych o złożonej geometrii. Sprawozdanie z realizacji grantu KBN nr 7 S102 035 04". Warszawa, 1995. 